\title{
Effective Management of Resources to Support Sustainable Development and Move towards Ecological Civilization: Experience of the Republic of Azerbaijan
}

\author{
Urkhan Alakbarov \\ The Academy of Public Administration under the President of the Republic of Azerbaijan, Baku, Republic of \\ Azerbaijan \\ Email: alakbarovuk@gmail.com
}

Received 16 June 2014; revised 24 July 2014; accepted 7 August 2014

Copyright (C) 2014 by author and Scientific Research Publishing Inc.

This work is licensed under the Creative Commons Attribution International License (CC BY).

http://creativecommons.org/licenses/by/4.0/

(c) (i) Open Access

\begin{abstract}
Insert environment that will foster the effective management of natural resources. This is one of the significant prerequisites for managing development processes in a sustainable way for transitioning to what is defined below as an ecological civilization. The research presented in this paper compares gross domestic product (GDP) per unit of energy consumed in the world, in the oil and gas exporting countries and in the Republic of Azerbaijan. The analyses are based on figures which were published in 2013-2014 by international organizations and they refer to the years 20002012. The analysis shows that at the present time, the efficiency of energy use in the Republic of Azerbaijan is $23 \%$ higher than the world average. The Republic of Azerbaijan has also attained one of the leading positions in the same sustainable development indicator among the oil and gas exporting countries. This was achieved throughout the last decade due to the implementation of policies directed at human capacity building through formal and informal education, in-service training of civil servants and increasing public awareness and participation.
\end{abstract}

\section{Keywords}

Public Administration, Sustainable Development, Ecological Civilization, Resources Management, Energy Efficiency, Human Capacity Building, Climate Change

\section{Introduction}

It is imperative to improve the administrative planning process in order to avoid poor management practices in

How to cite this paper: Alakbarov, U. (2014) Effective Management of Resources to Support Sustainable Development and Move towards Ecological Civilization: Experience of the Republic of Azerbaijan. Journal of Human Resource and Sustainability Studies, 2, 131-135. http://dx.doi.org/10.4236/jhrss.2014.23012 
development which are classified as "development without future" and "development without equality”. Improving management practices in order to aid in the reduction of poverty was identified as a priority by the UN in the document "The Millennium Development Goals" (MDG), which was adopted at the outset of the $21^{\text {st }}$ century, during the MDGs World Summit [1]. Along the same lines securing sustainable development through effective planning and management will remain a central priority in the post 2015 development agenda [2]. Resolving issues occurring in the day-to-day administration of the natural, economical, social and political environment as unique system to implement the sustainable development technologies and provide transition to an ecological civilization are important for economic and environmental security. The concept of ecological civilization as well as the term "ecological civilization" and its short version "ecocivil" has been developed and proposed as a way to deter negative tendencies in development processes [3].

Successful management of sustainable development processes requires utilization of various measures. Resources planning and management, including human capacity building for rational mobilization of renewable and non-renewable resources is a subject of particular importance. Building human capacity for sustainable development, using natural resources more efficiently, and transition to an ecological civilization will require both increasing occupational and professional knowledge and skills through formal and informal education, and the in-service training of civil servants. Increasing the population's general knowledge and awareness is also an important element to these activities. This paper is dedicated to the discussion of managing resources to increase sustainable development.

\section{Methodology}

Effective use of energy resources is essential for sustainable development and there are various methods used in evaluating whether these resources are used. One of the widely proven methods for measuring the efficient use of resources is the index showing the consumption of energy needed to produce gross domestic product (GDP). Two characteristics of this index are mostly used in international statistics [4]. One of them demonstrates the value of goods and services, produced using each unit of consumed energy. In order to make a comparison between countries or regions using this method of evaluation, it has been commonly accepted to use the quantity of energy contained in $1 \mathrm{~kg}$ of oil as an energy unit. The average cost per $\mathrm{kg}$ of oil during a particular year is the same throughout the world. Therefore, the use of this methodology and the application of this equivalent of energy make it possible to assessing energy efficiency when the energy has been received from different sources. The cost of goods and services produced with the volume of energy equivalent to the amount of energy in one kilogram of oil is calculated in US dollars. Thus, the cost of produced goods and services is provided taking into account the PPP (Purchasing Power Parity), which is identified by the World Bank for each country.

Another evaluation method is to compare the amount of energy needed to produce US\$1000 of GDP. Both methods emphasize the importance of efficient planning and management of natural resources, in order to maintain sustainable development and a green economy. This paper compares the volumes of GDP per energy unit in the Republic of Azerbaijan with both the world average and with other countries. The comparative assessments are based on figures from the years 2000-2012 which were published by the World Bank, UNDP and other international organizations in 2013-2014.

\section{Results}

The indices presented in Figure 1 show that the per capita GDP growth in the Republic of Azerbaijan has increased more than 3.4 times over the course of 10 years [5]. While of course not the only measure of national progress, this is a significantly high indicator of economic development. It is particularly important however to note that this growth is accompanied by an increase in the efficient use of energy resources. This growth is crucial not only to the national and regional economy, but has been done in such as way as to reduce human footprint, which is essential in relation to global climate change. The reduction of the greenhouse emissions into the atmosphere is the point this paper seeks to emphasize [6].

The data presented in Figure 2 represent comparisons of the volumes of the GDP per energy unit in the world and in the Republic of Azerbaijan. These figures refer to the years of 2004-2011 and were published by international organizations in 2014 [7]. The graph shows that until 2009 the economic efficiency of energy use in Azerbaijan lagged significantly behind the average world figures. In 2004, the average world figures on GDP production per consumed energy units were 2.2 times higher than the national indicators of the Republic of 


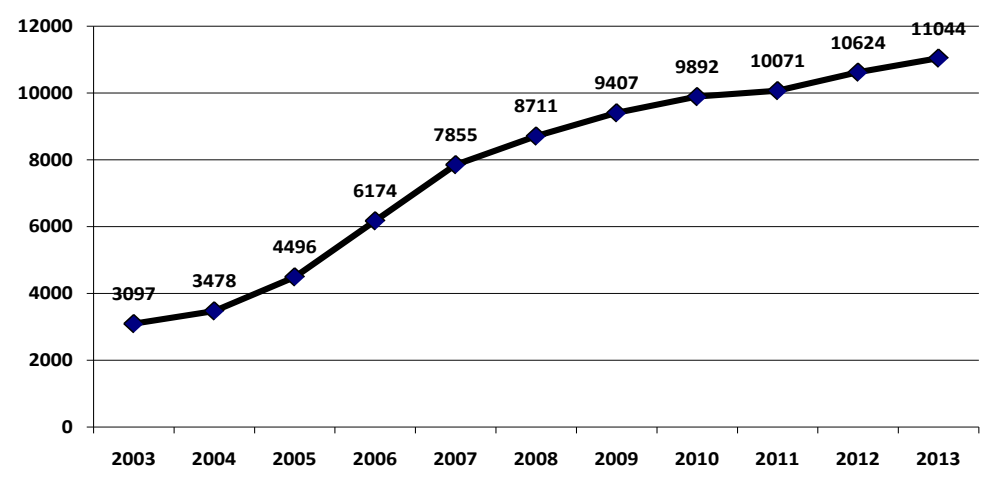

Figure 1. GDP per capita, USD with PPP, Republic of Azerbaijan, 2003$2013[5]$.

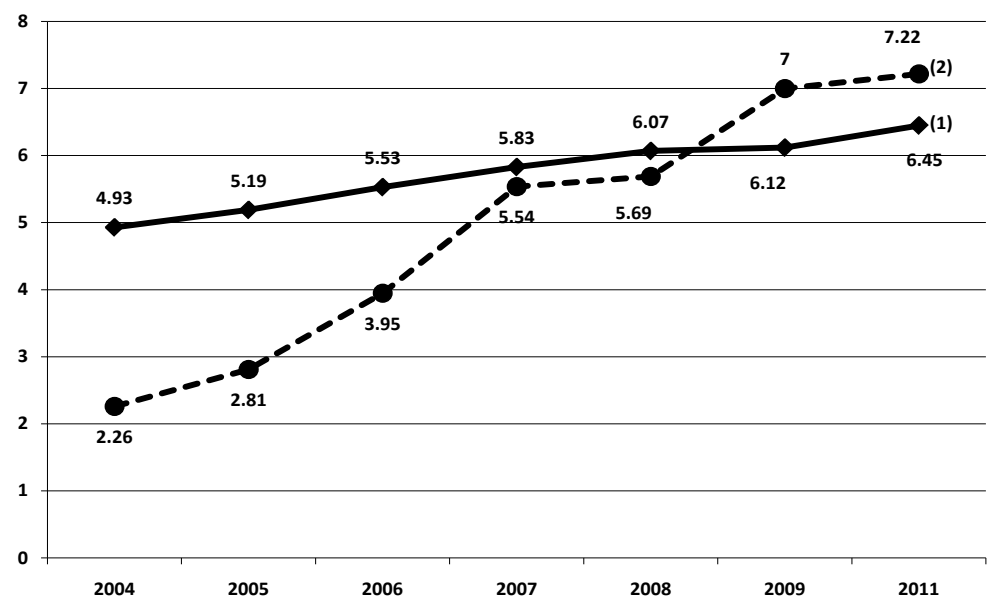

Figure 2. Energy efficiency: GDP (USD with PPP) per unit of energy (1 kg of oil equivalent) used: (1): world, (2): Republic of Azerbaijan [7].

Azerbaijan. In 2007 this difference dropped down to 5\%. Beginning in 2009 the Republic of Azerbaijan’s figures pulled ahead of the world average and by 2011 the volume of goods and services produced in the country per energy unit was $23 \%$ higher than the world average. This happened because growth rates in the efficient use of energy resources in the country between the years of 2004-2011 were higher than the growth of average world indicators. This was also due to the implementation of policies directed towards expanding the knowledge and abilities of civil servants and policy makers who were working in development planning and management.

It can be concluded that the increase in the efficient use of energy resources is connected to the sector of the country's economy associated with the production and export of oil and gas. In this case, similar trends have been observed in other oil and gas exporting countries. Characteristics of these for nine oil producing countries, including Azerbaijan, indicators are presented in Figure 3. The data shows that during 2003-2011 all countriesexporting hydrocarbons increased their energy efficiency. However, in the Republic of Azerbaijan this process has been even more efficient. In 2003 reporting from international organization indicated that the Republic of Azerbaijan took one of the last places among the reference countries. From 2003-2011, GDP per unit of energy in Azerbaijan is increased by more than 3 times. As a result, the Republic of Azerbaijan took second place behind Norway among the reference countries in terms of rational management of energy resources for GDP production [8]. Azerbaijan's growth has placed this country in a better position to manage the economy and its resources more efficiently. The country has modernized its methods of management and has gained increased ability to raise the population's awareness of energy consumption.

Managing natural resources to aid in the transition to sustainable development involves more than just extensive education at all levels. It is also necessary to raise the general population awareness about sustainable development and the transitioning to an ecological civilization as defined earlier. There is a three-pronged approach to education, training, and awareness creation on regulation, planning and management for sustainable 
2003

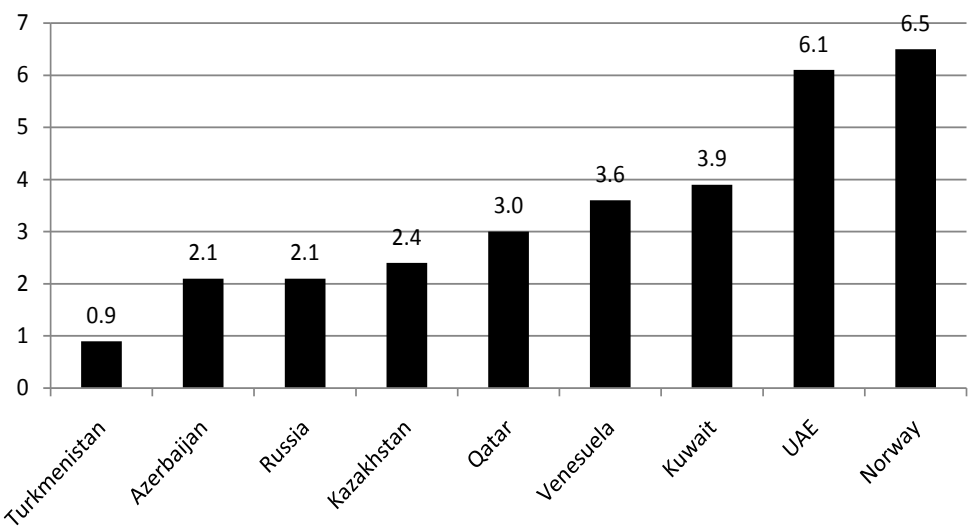

2011

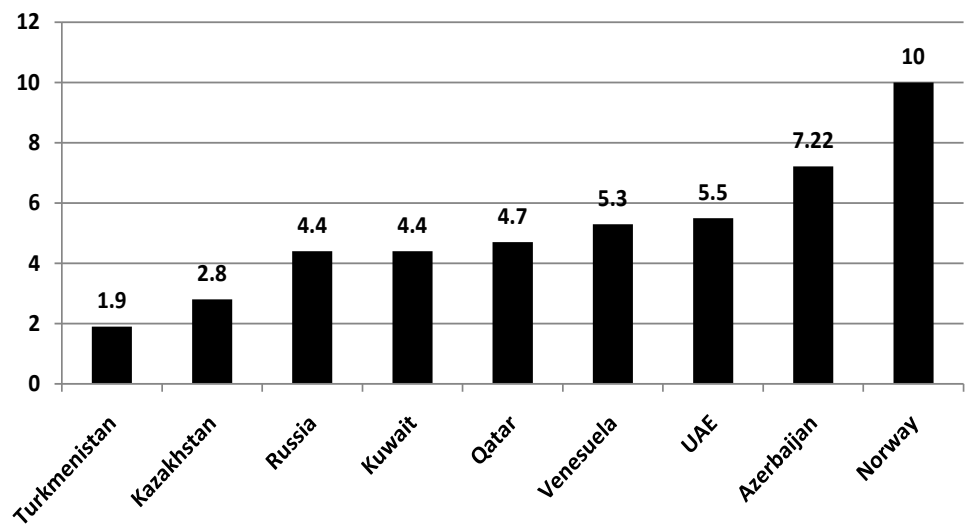

Figure 3. Azerbaijan Republic, oil \& gas exporting countries: GDP per unit of energy use (2003-2011, USD with PPP per kg of oil equivalent, [8].

development and security:

a) to introduce regulation, management principles and mechanisms supporting sustainable development to policy makers;

b) to use professional training to introduce underlying concepts to technical personnel in secondary and tertiary schools; and

c) to raise general awareness of the population through mass media exposure.

Inspiring a new generation to successfully complete projects will require the active participation of everyone interested in innovative development guided by science and the latest technology.

Sustainable development is a key tool for prevention and alleviation of the negative processes in development. This approach will necessitate participation from the specially trained civil servants who have been educated in delivering the highest quality and quantity of social goods and services at national and regional levels. The modern philosophy and practice for effectively managing the environment is compromised of natural, economical, social and political components and is based on sustainable development and the principles and technologies of ecological civilization [9].

Using this approach will create an environment where well trained and qualified administration specialists in the public sector exercise effective management and decision making skills by tapping into their existing talents and resources. Relevant knowledge, training and commitment of this key group of professionals are critical to the implementation of the desired management and administrative goals. These principles embrace accountability and transparency as well as innovation, out-of the box thinking and use of modern technology. This group of professionally trained decision makers and managers are responsible for ensuring that the social contract between the government and its constituency and key client-the population is fulfilled. This contract has the ob- 
jective of delivering the highest attainable quality and quantity of social goods and services and assures responsibility of the state towards protection the well being of the people. Therefore, continuous enhancement of the skills and knowledge of government personnel as well as private sector representatives is the most important task of the specialized tertiary schools and academies.

In short the main objective of these new policies and procedures of the state is to mobilize the use of scientific and technological innovation for national development planning and management. Ultimately, this should translate into achieving sustained development, economic prosperity, better planning, promotion, and use of social services, and the eventual transition to green economy and ecologically civilized society. To drive this vision forward it is essential to create solid human resource base that is technically qualified and savvy in management practices. A vision, and targeted financial and human resources to implement the vision are essential to overcoming the economic, social, cultural, and political challenges that are universal in the context of the current global trends. Only if these conditions are met is the transition to a more ecological civilization possible.

\section{References}

[1] Millennium Development Goals. 24.02.2014. www.un.org/milleniumgoals/

[2] http://wikiprogress.org/index.php/Post-2015_Development_Agenda:_Goals,_Targets_and_Indicators 24.02.2014

[3] Alakbarov, U.K. (1998) Ecologization of Human Activity. Energy, Ecology, Economy, 141-143.

[4] Human Development Report, 2013, UNDP, New York, 202 p.

[5] Список стран по ВВП (ППС) на душу населения. 26.05.2014 http://ru.wikipedia.org/wiki/Список_стран_по_ВВП_(ППС)_на_душу_населения

[6] Climate Change Policy and Practice (climate-I.iisd.org/news/unep-world), 20.052014

[7] GDP Per Unit of Energy Use (PPP \$ Per kg of Oil Equivalent. http://search.worldbank.org/data?qterm=GDP+per+unit+of+energy+use\&language=EN\& format=GDPperunitofenergy use(PPP\$perkgofoilequivalent

[8] World Development Indicators \& Global Development Finance. http://data.worldbank.org/data-catalog/world-development-indicators

[9] Alakbarov, U.K. (2010) Capacity Building for Transition to Ecological Civilization. Proceedings of the "Man and Biosphere” (MaB, UNESCO) Azerbaijan National Committee, 6, 5-12. 
Scientific Research Publishing (SCIRP) is one of the largest Open Access journal publishers. It is currently publishing more than 200 open access, online, peer-reviewed journals covering a wide range of academic disciplines. SCIRP serves the worldwide academic communities and contributes to the progress and application of science with its publication.

Other selected journals from SCIRP are listed as below. Submit your manuscript to us via either submit@scirp.org or Online Submission Portal.
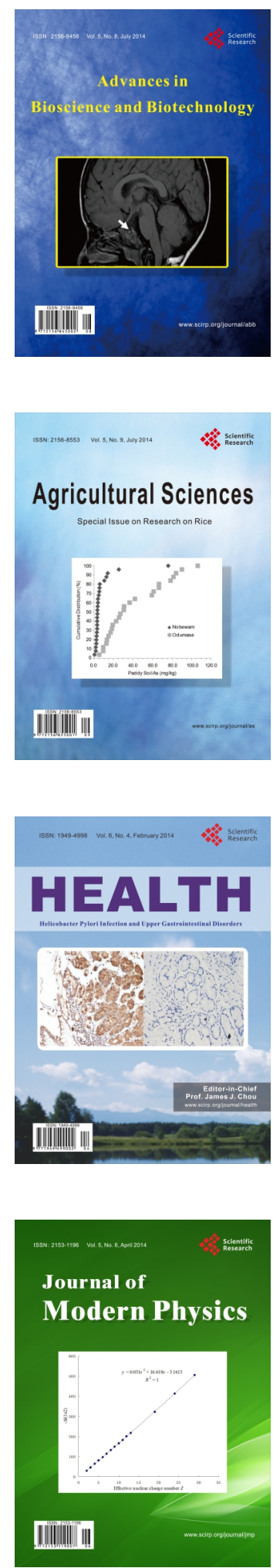
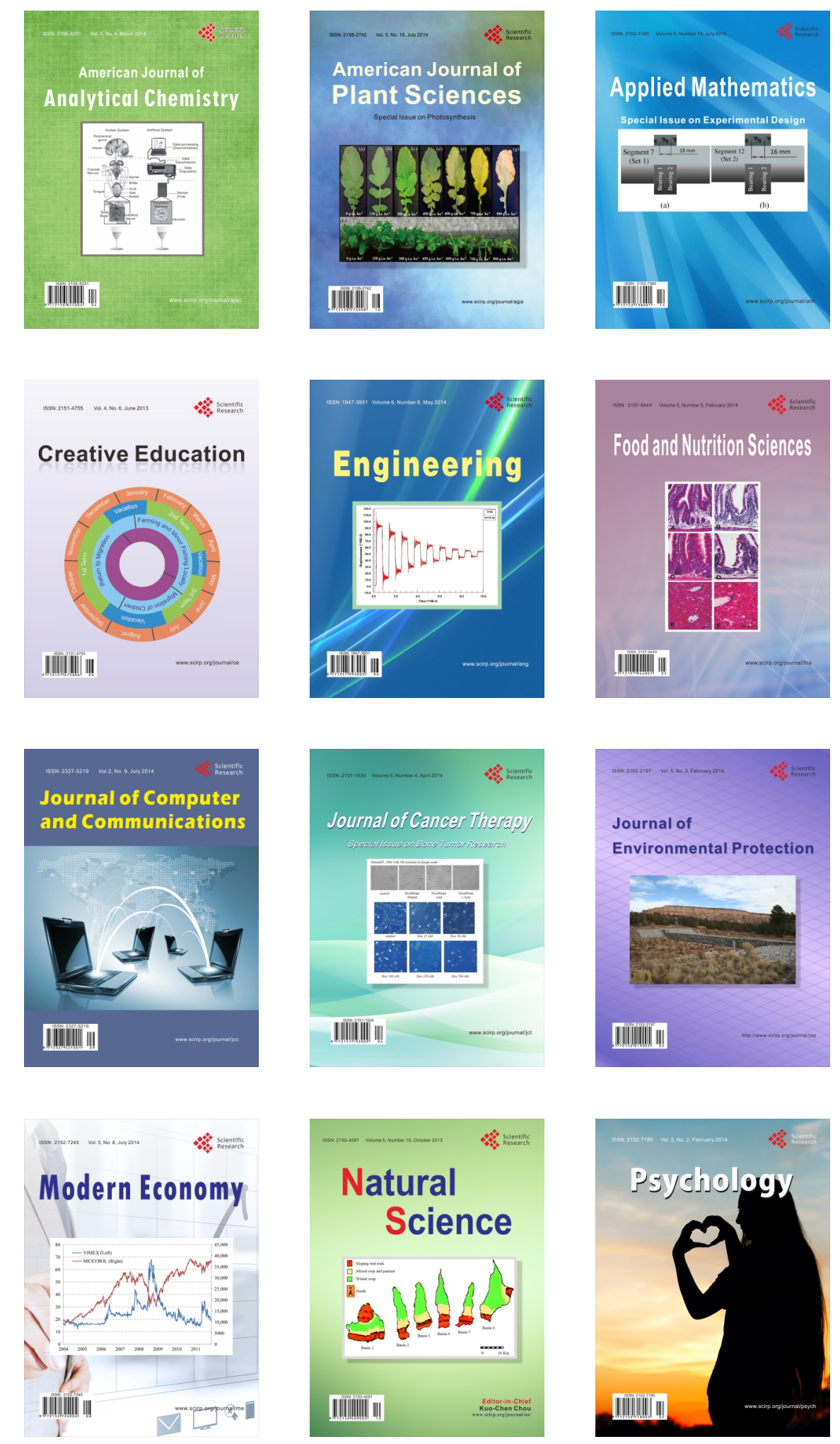